\title{
INVESTMENT BANKING METHODS PRIOR TO AND SINCE THE SECURITIES ACT OF 1933
}

\author{
Paul P. Gourrich*
}

\section{INTRODUCTION}

This discussion of investment banking methods and the effects of the Securities Act of 1933 upon the practices in the distribution of securities cannot possibly possess the stamp of finality. Certain limitations must constantly be borne in mind.

For example, there is not always agreement among persons active in the origination, underwriting, and distribution of securities as to the meaning and significance of some of the observed changes; consequently, many of our interpretations and conclusions represent statements of opinion.

Then, too, we are dealing with a very brief period of time, considering that our problem is to evaluate and decide upon economic trends. The Securities Act of I933 has been operative for about three and one-half years, and during the first half of this period there was little or no corporate financing of the sort which required investment banking assistance. Therefore, many of the features of today's investment banking mechanism are probably no more than the tentative adjustments of this industry to the changing economic and financial background. We most certainly have not yet seen all, or even most, of the permanent effects of recent legislation.

This conclusion is strengthened by our knowledge that the Act itself is still in the process of being interpreted and defined. These adjustments will continue as the administration of this legislation is oriented to new facts and to the changes which are, themselves, a result of this new machinery.

Any analysis of the effects of the Securities Act upon the methods of distributing securities at the present time cannot overlook the fact that the period since the passage of the Securities Act has not only been short, but also somewhat unique in economic history. We have been operating during years of transition, while our productive and financial economy has been moving towards a new phase in its development. Business and finance are not only convalescing from a major depression, but are also faced with new problems and operating conditions, of which this legislation is

- Director of Research Division, Securities and Exchange Commission. Former Head Economist of Kuhn, Loeb \& Company, New York City. The author was assisted in the preparation of this article by Mr. S. L. Osterweis of the Research Division of the Securities and Exchange Commission. 
both cause and effect. It is clear that some changes would have occurred in the methods of investment banking merely because of the change in financial background. Certainly, the trend towards greater disclosure and publicity in finance, which is the cornerstone of the Securities Act of 1933 and the Securities Exchange Act of I934, had started prior to the establishment of the formal requirements of these statutes.

Despite this trend, publicity of investment banking operations was not general prior to the Act. Thus, it is likely that in many matters our knowledge of past conditions is not complete. There is no certainty that we have detected all significant changes or similarities in present methods as compared with those of the 'twenties.

However, in spite of the weight of these limitations, we have enough data intelligently to discuss and describe present methods, and to gain some impression of the effect of the Acts and the Commission upon the technique and problems of the investment banker.

\section{Significance of the Problem}

The importance of investment banking as an industry is sometimes not fully understood. The average annual gross income from the primary distribution of securities during the period from 1926 through 1930 may be roughly estimated at $\$ 400,000,000$, and, for 1929 alone, at over $\$ 600,000,000 .^{1}$. While these figures are by no means a complete picture of total investment banking income ${ }^{2}$ they are equal to or greater than the gross commission or interest income reported by all stock exchange member firms and members during the same period. ${ }^{3}$

Such gross income is roughly of the same sort as "value added by manufacture" in the case of a manufacturing industry, and a comparison with figures in this category would place investment banking among the first eighteen industries during the period $1926-3^{\circ}$ and among the first thirteen for the year 1929.4

However, even more important than such considerations of size, is the fact that investment banking is one of the channels through which the nation's savings are collected and distributed to the consumers of capital. The accumulation of savings and their distribution to industrial borrowers are linked to the basic problems of maintaining "balance" in our economy, and thus to the promotion of an efficient economic and stable social structure. Fundamentally, the protection of the investor lies not merely in "truth" and "disclosure," as such, but also in the prophylactic effects of publicity in removing artificial pressures from the capital market, and in

\footnotetext{
${ }^{1}$ These figures have been arrived at by applying an estimated gross spread of $3 \%$ to the value of all corporate and foreign bonds sold during the period, $1 \%$ to the value of all state and municipal issues (excluding United States government securities) and $8 \%$ to the value of all stock issues.

2 These figures do not include investment bankers' profits or losses from secondary distribution, trading accounts and similar operations which, at least in certain years, were probably as important as primary distribution or more so.

Stock Exchange Practices, Pt. 17, Hearings before the Senate Committee on Banking and Currency, 73rd Cong., 2nd Sess. (1934), Statements of Income and Expense, pp. 7869, 7875, 7881, 7885, 7899, 7921.

-U. S. Bureau of the Census, Census of Manufactures (1927, 1929, 1931).
} 
thus restricting the production of investment instruments to those economically desirable.

\section{Investment Banking Methods Prior to the Securities Act of $1933^{\circ}$}

Investment bankers' participation in the distribution of new securities has taken two major forms: (I) the distribution of securities to the public after the banker has purchased the issue from the issuer, or received an option thereon, or with the banker acting as selling agent; (2) the "underwriting" of an offering of -securities by a corporation to its security holders, by which the banker obligates himself to purchase all unsubscribed securities. In the following discussion, I shall not concern myself with the second of these to any great extent. Since the Act there have been relatively few offerings of this sort (although they are beginning to increase in number), and thus, while the method is an important phase of investment banking, we do not need to discuss it in considering changes caused by the Securities Act.

\section{A. Origination}

The first step in investment banking, generally termed "origination," consisted of the negotiations and investigations preliminary to any financing, and, later, the contracting of the banker or bankers with the corporation issuing the securities to be distributed. In the 'twenties, the origination of most issues was handled by one investment banker, and this one banker would generally be the only house to deal directly with the issuing corporation.

The choice of the banker usually followed from past relationships. It was customary for one firm to originate all the issues of an established corporation, and, consequently, there was a certain continuity of relationship between bankers and issuers. In the case of securities of corporations with no previous public financing where there were no such relationships, the banker or the corporation would frequently secure the business through the initiative of an intermediary, a "finder," who would bring the two parties together.

Before a banker would make any commitment with a corporation, particularly in those cases where he had not previously sold its securities, it was customary for him to engage in a rather thorough investigation of the issuer. From such an investigation, he would first decide whether or not he desired to assume a banking sponsorship towards the issuing corporation, and, if this preliminary decision were favorable, the detailed analysis of the issue would aid the banker further in appraising the quality of the risk which he was about to undertake, and then in determining the types of securities to be issued and the prices at which they should be offered to the public. This investigation was of great importance, because of the reliance

\footnotetext{
'The following discussion is based on methods used during the period from 1920 through 1930, or the 'twenties.

- Apparently the absence of many offerings to security holders is not an effect of the Act but rather a reflection of the stage in the business cycle in which we are operating. This is confirmed by the relatively greater number of such offerings in recent months, as more and more people are accepting the fact of a business recovery.
} 
placed upon the name of the originating bankers and their judgment in choosing securities by other investment bankers who might participate in the "underwriting" and distribution of the issue, and eventually by the buying public. This investigation by the originating banker, and his decision based upon such investigation, were therefore substituted for any independent analysis by security buyers. Unfortunately, there were cases where the investigation was so perfunctory as to be of no significance, and when this occurred the mechanism was weakened at its very base, and investment banking became susceptible to serious abuse.

The ultimate contract with the corporation in the case of most bond and better grade stock issues was for a firm commitment to purchase, subject to approval of counsel. In the case of some stock financing, particularly issues of smaller and more speculative ventures, the contract would be for conditional purchase, or would provide that the originating banker would have an option to purchase or perhaps act as selling agent for the issuing corporation. In all types of financing, there was some use in these contracts of "market" or "market out" clauses, which gave the bankers the right to cancel their purchase commitments because of changes in market conditions. ${ }^{7}$ These were not the rule, however.

\section{B. Syndication}

While the origination of an issue would generally be handled by one firm, the remainder of the investment banking process was a series of steps, the purpose of which was to associate other firms and persons with the financing. This process generally assumed the form of an inverted pyramid, with the originating banker at the apex, with an increasing number of firms at each step, and with the base consisting of the selling group members. It is called "syndication," and required the formation of various groups and syndicates, the purposes of which were two-fold. Firstly, it was desired to spread the burden of the originating firm's liability to take up the issue from the corporation. Secondly, it was necessary to set up a mechanism which could distribute securities, and therefore to associate with the financing the actual retailers of securities, who as selling group members made up the base of the pyramid.

The first stage in syndication usually occurred almost simultaneously with, and sometimes before, the signing of the purchase contract, when the originating banker would invite other firms to participate in the financing. He would offer such participations on the same terms as those in his contract with the issuer (except that, in such cases, he would generally receive a small fee for originating and managing the issue), or he might form a relatively small group, in which he would have a sizable interest, and this group would purchase the issue from him at a slight increase over the original purchase price. The formation of these groups enabled the originating firms to spread the purchase risks attached to an issue. It also permitted them to make participations available on favorable terms to houses which would

\footnotetext{
${ }^{7}$ For a discussion of the employment of such clauses at the present time, see pp. 56.57, infra.
} 
be particularly helpful in distributing the issues, to those which had in the past reciprocated, or might at a later date reciprocate business or be useful in some other manner, and to those whose inclusion in the business was suggested by the issuing corporation.

The next stage in syndication involved the association of retailing organizations or dealers with the financing. ${ }^{8}$ Three alternative methods for coördinating dealers were employed in the 'twenties. These methods varied in the extent to which dealers were required to take over the function of assuming risks; but in all cases, members of the groups were expected to sell securities. For the most part, these three methods were successive, in the point of time, although there was some overlapping.

The first stage was the unlimited liability selling syndicate. In such a group, the participant agreed to have a pro rata share in the purchase of the issue by the syndicate and further agreed to take up his share of any unsold securities remaining in the syndicate upon its expiration. In addition, each participant had the right to sell securities, receiving a commission on all such sales. However, no matter what the amount of his sales or whether or not they exceeded the amount of securities for which he was liable, he still retained his liability to take up his proportionate share of unsold securities.

The next stage was the limited liability selling syndicate, in which the responsibility of each participant to take up securities was specifically reduced by the amount of his sales. For example, if a dealer's participation in such a syndicate were \$100,$\infty 00$ of bonds, and he sold $\$ 100,000$ of bonds, he would have no further liability in this respect, even though the syndicate as a whole had a quantity of unsold securities. However, both unlimited and limited syndicates generally carried the risks of the syndicate trading account, and since this liability was unaffected by a participant's sales, he did not completely restrict his risk.

The third phase was the selling group, where the dealer relieved himself of all liabilities except those of the actual retail distribution of securities. He no longer carried the liabilities for the syndicate trading account. Each dealer merely agreed to take up for resale a stated number of securities in accordance with fixed public offering terms, in return for a stated selling commission as compensation. The members' real financial liability was restricted to taking up the amount of securities for which they subscribed. In some instances the liability of the selling group was even less, when there were no allotments of securities but the members merely subscribed upon receipt of orders from customers. The selling group functioned much

\footnotetext{
- It was customary for those originating and wholesaling firms which had distributing organizations to participate as retailers in any financing with which they were associated. This was an important factor, since, by the end of the 'twenties, most of the large firms had substantial sales forces. The bank affiliates were particularly active in constructing substantial retail organizations and would generally retail approximately one-haif of the amount of securities for which they had committed themselves as originators or members of one of the purchase groups.
} 
the same as the limited liability syndicate, but, not carrying the trading account liability, its risks were only those connected with retail distribution.

As the above description of these three stages in syndication indicates, there was a tendency throughout this period for the dealers to carry less of the liabilities in connection with the original purchase of an issue, and to restrict themselves solely to its distribution. This tendency may be further described as one towards a separation of the two functions of risk assumption and selling. It was contemporaneous with the development of large selling organizations by many of the dealers, as well as by a large number of the leading originators of securities, particularly the security affiliates of commercial banks.

This separation of functions, which took place when the selling group and the limited liability seiling syndicate were used, was accompanied by the formation of an intermediate or "banking" group. By this means, the purchase group members assured themselves that their liabilities would be spread or insured. When the selling group was used, this intermediate syndicate aided in carrying the liabilities of the trading account. The banking group was frequently formed about the same time as, or prior to, the formation of a selling group. It distributed the risks assumed by the purchase group over a larger number of firms than the ten or fifteen, and sometimes less, who participated in such purchase groups. This function might be performed by the banking group purchasing the issue from the purchase group and immediately offering it to the selling group or syndicate, or by this banking group agreeing to take up any securities which the purchase group might fail to sell to or through the selling group; i.e., "underwrite" such sale. Its job, in any case, was to stand ready to take bonds not sold to or through the selling group; in addition, it bore any risks of the trading account in the new issue. In many case. however, participation in a banking group was relatively riskless, because of the fact that, prior to or simultaneously with the formation of such a group, the issue might have been sold to the selling syndicate. It is clear that, to a certain extent, the group was used not only to distribute liabilities, but also for the purposes of giving favors to and gaining business from larger and powerful houses, and of giving extra compensation to large distributors.

The general mechanism of syndication which we have described was set up to sell an issue at a fixed price. As one part of this, the manager stood ready to buy the new issue in the open market when price weakness appeared during the period of distribution, and thus maintain this fixed public offering price. This process, usually conducted by the trading account, is now referred to as "pegging, fixing and stabilizing."

Such trading enabled the distributing bankers to provide some demand for the issue in the open market, which would be lacking if the issue were not well received and which might also be absent for technical reasons. During the period of distribution, the demand for a security at the public offering price would not generally 
evidence itself on exchanges where commissions must be paid, but would restrict itself to purchases from dealers selling the new issue on a net basis at the public offering price. Thus, whatever offerings were made by the public in the open market, while distribution at the public offering prise was continuing, would frequently meet no demand at this price and therefore might tend to reduce the market price below the offering level.

Any decline in the quoted market price substantially below the offering price might disrupt the distribution of an issue, and the bankers attempted to avoid this by supplying demand for the issue at the offering price, through the bidding and buying of the syndicate trading account. ${ }^{\circ}$ When the need for this support was deemed likely, the distributing bankers would attempt to supply themselves with buying power by over-selling the issue, although clearly if the issue were unsuccessful it would be difficult to sell even the amount of the issue, much less accumulate a short position. The covering of the short position provided the needed support when liquidation appeared. Out of a sample of fifty-nine bond issues sold in 1928, trading accounts were employed in the distribution of forty, or about two-thirds. The tbtal purchase of such accounts averaged about $7 \frac{1}{2} \%$ to $8 \%$ of the total amount of bonds offered, and total purchases and sales were, on the average, below $15 \%$ of the amount of the offering. ${ }^{10}$

Further analysis of these bonds brought out during 1928 indicated that the issues for which syndicate trading accounts were formed sold at less favorable prices after "seasoning" than did the issues without such accounts. After correcting for changes in the general level of bond prices, it was found that issues with trading accounts sold, on the average, at $91.3 \%$ of their offering price, during their second year after offering. However, issues without trading accounts sold at $95.2 \%$ of their offering prices during the same year. While both types failed to perform as well as the market, the failure of the issues with trading accounts was significantly greater than the failure of the issues without trading accounts. These relationships do not necessarily indicate that trading accounts were responsible for poor behavior. They do, however, suggest possible weaknesses of such practices.

Whether or not there was justification for syndicate activity in the market in order to maintain the public offering price, the mechanism created to carry on this trading was capable of abuse, and was abused during the 'twenties. There was no disclosure of the position or activity of the syndicate trading account, so that frequently the volume of its trading was much in excess of that required to take care of a "normal" market supply of securities resulting from the over-flow of distribution, and instead created a manipulative and highly artificial price.

This process of syndication performed the two-fold purpose of assuring an issuing corporation of the desired funds (and distributing the risk involved in such guar-

'It is also alleged that such trading accounts may, at times (particularly in distributions of stoeks), act to stabilize the market in the other direction by selling securities and thus restricting excessive price rises.

10 These figures for purchases and sales of the trading account include, in addition to open-market transactions, trades with members of the selling group or syndicate. 
antee or purchase), and of constructing a retail or distributing organization for placing the securities in the hands of ultimate buyers. The system was geared up for wide distribution. Selling groups or syndicates generally consisted of a large number of dealers widely scattered throughout the United States, and sometimes abroad as well. The number varied, of course, with the size of the particular issue; it was perhaps 300 for an issue of about $\$ 15,000,000$ of bonds and for larger issues sometimes exceeded 800 or 900 . Among this number were many retailing organizations, particularly the bank affiliates, which had widely scattered branches and were themselves capable of selling securities in every part of the United States.

Syndication was also set up in order that securities could be disposed of rapidly, and the liabilities and risks which followed from carrying an inventory kept at a minimum. So far as the originating or wholesale houses were concerned, this was accomplished by the speedy formation of selling groups or syndicates. So far as the retailer was concerned, speed was achieved by having efficient and extensive selling organizations. The rapid pace was sustained through the actual retail distribution because of the condition of the capital markets which prevailed during most of the 'twenties. Issues could be sold within a very short space of time after the original public offering, sometimes less than twenty-four hours. This fact, together with the absence of public information concerning an issue prior to the offering date, made it impossible for many buyers of securities to have much knowledge of what they were purchasing.

The compensation to the investment banker for this underwriting and distribution of securities varied, of course, with the particular issue. As a general rule, the gross compensation is measured by the difference or "gross spread" between the price at which the originating banker purchased the issue from the issuing corporation, and the price at which dealers and retailing organizations sold to the public. What figures we have, and these are not complete, indicate that from the period from r920 to $193 \mathrm{I}$ the average gross compensation on issues of all domestic railroad bonds was slightly less than $3 \%$ of the par value of such issues, and for most, if not all, foreign bonds sold in the United States, 5\% of par value. For the years 1927 to I93 for a sample of high grade domestic corporate bonds, the average spread was about $3 \%$ of par value.

With the exception of the railroad issues, which include all issues approved by the Interstate Commerce Commission, our most trustworthy sample is for sixty-five bond issues of $\$ 3,000,000$ or more offered during 1928 . The gross spreads for such issues varied between $1.84 \%$ and $8.01 \%$ of the public offering price. ${ }^{10^{2}}$ The average was $4.28 \%$ with about $83 \%$ of such issues having spreads of more than $2.70 \%$ of public offering price.

The gross spreads on a sample of preferred stock issues of $\$ 2,000,000$ or over floated in 1929 (nineteen in number) averaged about $5 \%$ of public offering price.

\footnotetext{
100 Other spreads for bonds have been expressed as percentages of par or face value. This difference is not of great importance since, on the average, bonds are originally sold at or very close to par or $100 \%$.
} 
The entire gross spread did not go into the pockets of the originating investment bankers, but was distributed among a large number of firms. Each syndicate or group would receive a portion of the gross spread, and the originating bankers participated in diminishing quantities in each group from purchase to selling group. Thus they retained the entire spread on only a portion of the issue, and hence, while the investment banking machine, as a whole, was compensated by the gross spread, this is not the measure of the profits of the originating firms. All gross profits were also subject to the expenses of distribution, which included charges for advertising, legal and other services, although these were sometimes paid, in part or in whole, by the vendor or issuer corporation. Perhaps the most important potential charge against gross profits was the possible and frequent losses from trading account operations.

\section{Summary}

The outstanding characteristic of investment banking during the 'twenties probably was the speed of distribution. It appears that there was a definite tendency for the policy of investment bankers to be dominated by their knowledge of the fact that the mechanism of syndication would permit rapid and effective selling, at times regardless of the quality of issues. In part, this was possible because all the participants in syndication and the ultimate buyers placed much reliance on the originating and participating bankers and their judgment in choosing a new issue. When this judgment was directed by thoughts of immediate profit, when investment bankers made their decisions to associate themselves with the distribution of an issue not on the basis of conservative appraisals but rather because of the clamor of their distributing organizations for securities, when, in other words, the "tail" began to "wag the dog," this reliance on the originating banker was unsound. In fact, this faith, instead of protecting the investor, led him astray. Furthermore, the ease of selling poor quality and overpriced securities was enhanced by the frequent absence of adequate information for buyers of securities and for security analysts and experts, who might aid buyers in reaching considered judgments. Sometimes, the information was not even available to the bankers, so that their judgment, though honest, might not have been based on enough information to be accurate; in many cases, whether or not the information was available to the firm, it was not disclosed to the public in an unambiguous manner. It is because of the many instances of these conditions which were revealed when, with the depression, the light of publicity was directed to these transactions, as well as the more shocking examples of suppression of factual data, that the Securities Act, based upon the principle of adequate disclosure, was passed.

\section{Investment Banking Since the Securities Act}

In discussing present investment banking operations we limit ourselves to issues registered under the Securities Act of 1933, and, for the most part, to bond financ- 
ing. ${ }^{11}$ These limitations do not affect our comparison with earlier methods, however, since registered issues have constituted the bulk of recent corporation financing, as is indicated by Table I which presents a summary of capital flotations during

\section{Table I. New Capital Flotations During i935 and 1936 \\ (Gross Proceeds of Issues over \$roo,000, Offered for Sale)}

(Millions of dollars)

\begin{tabular}{|c|c|c|c|c|c|c|c|c|c|c|}
\hline \multirow[b]{3}{*}{$\begin{array}{l}\text { Month } \\
\text { and Year }\end{array}$} & \multicolumn{5}{|c|}{ Corporate and Foreign Securities } & \multicolumn{4}{|c|}{ EXEMPT SECURItIES } & \multirow[b]{3}{*}{ 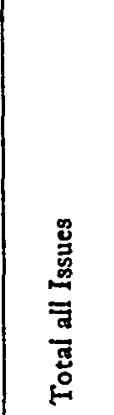 } \\
\hline & $\begin{array}{c}\text { Non- } \\
\text { Exempt }\end{array}$ & \multicolumn{3}{|c|}{ Exempt } & \multirow[b]{2}{*}{ 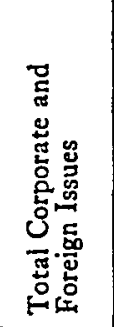 } & \multirow[b]{2}{*}{ 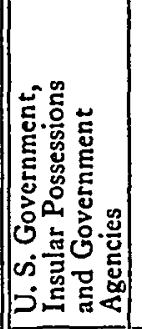 } & \multirow[b]{2}{*}{ 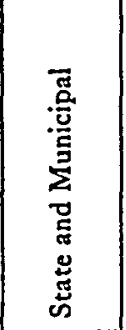 } & \multirow[b]{2}{*}{ 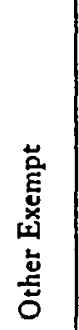 } & \multirow[b]{2}{*}{ 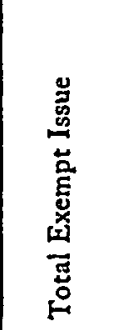 } & \\
\hline & 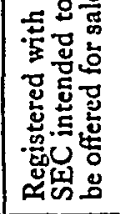 & 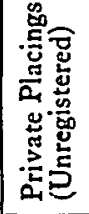 & 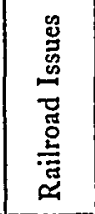 & 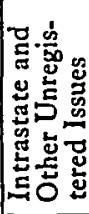 & & & & & & \\
\hline $\begin{array}{l}\text { Augu } \\
\text { Septe } \\
\text { Octol } \\
\text { Nove } \\
\text { Dece }\end{array}$ & $\begin{array}{c}9.1 \\
36 \\
124.6 \\
105.3 \\
121.3 \\
164.9 \\
476.8 \\
227.4 \\
244.3 \\
370.1 \\
250.8 \\
196.2\end{array}$ & $\begin{array}{r}45.6 \\
38.9 \\
.4 \\
6.9 \\
33.5 \\
51.4 \\
13.4 \\
31.6 \\
16.1 \\
25.4 \\
30.1 \\
4.2 \\
\end{array}$ & $\begin{array}{l}0 \\
0 \\
17.1 \\
27.3 \\
12 \\
12.4 \\
.6 \\
8.7 \\
9.1 \\
0 \\
0 \\
23.4\end{array}$ & $\begin{array}{l}.9 \\
1.1 \\
.6 \\
.3 \\
.3 \\
.3 \\
.3 \\
1 \\
0 \\
1.2 \\
0 \\
1.5\end{array}$ & $\begin{array}{c}55.6 \\
76 \\
142.7 \\
139.8 \\
167.1 \\
229 \\
491.1 \\
268.7 \\
269.5 \\
396.7 \\
280.9 \\
225.3\end{array}$ & \begin{tabular}{|c}
0 \\
0 \\
38.8 \\
32.1 \\
101.9 \\
455.9 \\
755.8 \\
199.6 \\
533.1 \\
26.6 \\
8.7 \\
1,089
\end{tabular} & $\begin{array}{r}96.5 \\
53.5 \\
148.3 \\
151.8 \\
.76 .7 \\
63.7 \\
87.4 \\
64.5 \\
147.2 \\
66.4 \\
108.7 \\
128.5\end{array}$ & $\begin{array}{l}0 \\
0 \\
0 \\
.6 \\
0 \\
0 \\
0 \\
5.5 \\
.5 \\
.1 \\
0.8\end{array}$ & $\begin{array}{r}96.5 \\
53.5 \\
187.1 \\
184.5 \\
178.6 \\
519.6 \\
843.2 \\
269.6 \\
680.8 \\
93.1 \\
117.4 \\
1,218.3\end{array}$ & $\begin{array}{r}152.1 \\
129.5 \\
329.8 \\
324.3 \\
345.7 \\
748.6 \\
1,334.3 \\
538.3 \\
950.3 \\
489.8 \\
398.3 \\
1,443.6\end{array}$ \\
\hline TOtal.. & $2,326.8$ & 297.5 & 110.6 & 7.5 & $2,742.4$ & $3,241.5$ & $1,193.2^{*}$ & 7.5 & $4,442.2$ & $7,184.6^{*}$ \\
\hline $\begin{array}{c}1936 \\
\text { January..... } \\
\text { Fcbruary.... } \\
\text { March..... } \\
\text { April....... } \\
\text { May } \ldots . . . \\
\text { June......... } \\
\text { July ........ }\end{array}$ & $\begin{array}{l}258.4 \\
175.9 \\
475.1 \\
613.2 \\
262.1 \\
335.8 \\
314.4 \\
208.6\end{array}$ & $\begin{array}{c}35.7 \\
.9 \\
25.1 \\
7 \\
0 \\
14.6 \\
78.3 \\
0\end{array}$ & $\begin{array}{c}48.0 \\
0 \\
127.4 \\
121.2 \\
49.9 \\
195.1 \\
49.6 \\
51.9\end{array}$ & $\begin{array}{r}1 \\
9.8 \\
2.9 \\
1.6 \\
3 \\
27.5 \\
3.3\end{array}$ & $\begin{array}{l}343.1 \\
185.7 \\
637.5 \\
744 \\
313.3 \\
598.5 \\
469.8 \\
263.8\end{array}$ & $\mid \begin{array}{r}18.3 \\
26.1 \\
1,401.0 \\
203.4 \\
24.7 \\
1,145.8 \\
0 \\
0\end{array}$ & $\begin{array}{r}123.6 \\
123.6 \\
123.6 \\
102 \\
98.7 \\
106.3 \\
41.9 \\
55.3\end{array}$ & $\begin{array}{r}.2 \\
5.2 \\
2.7 \\
.4 \\
5.3 \\
2.9 \\
1.3 \\
.7\end{array}$ & $\begin{array}{r}142.1 \\
154.9 \\
1,527.3 \\
305.8 \\
128.7 \\
1,255.0 \\
43.2 \\
56\end{array}$ & $\begin{array}{r}485.2 \\
340.6 \\
2,164.8 \\
1,049.8 \\
442.0 \\
1,853.5 \\
513.0 \\
319.8\end{array}$ \\
\hline TotaL & $2,693.5$ & 169.7 & 643.1 & 49.4 & $3,555.7$ & $2,819.3$ & 775.0 & 18.7 & $3,613.0$ & $7,168.7$ \\
\hline
\end{tabular}

Total after revision of the monthly figures for state and municipal issues. The actual total of the unrevised frures is $\$ 1,193,262,022$, for state and municipals, and $\$ 4,442,233,610$ for all non-corporate istues.

23 We do not concern ourselves with the financing of promotional ventures under the Securities Act, although this field is of much interest in connection with a study of investment banking. Apparently, it is difficult to raise funds for these companies, at least in part, because of the absence of banking assistance. Studies of the Commission have indicated the following facts with reference to these promotional ventures: (a) there is a general absence of any firm banking commitment, with only about one out of every twenty issues having firm underwriting; (b) there is apparent inability thoroughly to distribute these securities, since, of about $45 \%$ of the total amount and $40 \%$ of the total number of issues for which registration under the Securities Act was effective, not one share of stock nor one bond was sold within the year following the effective date of the registration statement, and, on the average for all issues, less than $20 \%$ of the amount effectively registered was actually sold within this period (about $85 \%$ of the total sales 
1935 and 1936. The only important class of corporate securities omitted are those of railroads, and only a relatively few have been sold during the past two years. ${ }^{12}$

Some of the characteristics of securities distributed since the Securities Act are, of course, different from those of issues sold during the 'twenties. Particularly important is the fact that most recent bond issues, and bonds have constituted the bulk of flotations, have been for the purpose of refunding outstanding indebtedness. They have sold at low coupon rates and very low yields. In fact, it is probable that, with respect to bond yields, recent financing has been somewhat unique.

A further influence is the fact that some recent redemptions have been carried out, in part, through the use of cash holdings of the issuing corporations, so that, as a result, there has probably been a shrinkage in the amount of corporate bonds outstanding. This probable restriction of supply and the very definite demand for high-grade securities have been important factors in the recent history of the capital markets.

\section{A. Origination}

The first change which is noted and which is a direct effect of the Securities Act is the changed structure of the original purchase of an issue from the issuing corporation. A substantial number of houses now sign the purchase contract with the issuer while, prior to the Act, it was customary for this contract to be made by only one banker and the company. In most cases, one banker still originates the issue, handles negotiations in connection with it, acts as manager of the purchase group, and directs the whole process of syndication, but the actual assumption of the contractual liabilities with the issuer or vendor is now generally made by a number of houses.

One of the reasons for this change is that, today, under the Act, there can be no offering of the bonds before the registration statement for the issue has become effective, or, generally, twenty days after the original filing. The information relating to the underwriting contract, etc., must usually be filed before the statement can become effective, and is customarily filed between the fifteenth and nineteenth day after original filing. This requires the contract to be signed several days before the effective date and the date of public offering. Since no offering can be made by the underwriters until the effective date, the result is that whoever signs such a contract bears the liability until the effective date, without being able to make any offering during this period in order to distribute such liability. Such liability can,

being made within the first six months after the effective date); (c) the investor pays a disproportionate cost for his investment in such companies because of the watering of stock by issues to promoters, the latter receiving, on the average, about three-quarters of the equity securities for less than one-quarter of the total investment, or about ten times as much as the public for an equal dollar of investment; (d) the expenses of distribution are high, averaging about $10 \%$ to $15 \%$ of the amount contributed by all investors.

${ }^{32}$ Even in the case of exempted securities such as those of railroads the effects of the Securities Act are noticeable. For example, a study of prospectuses used in connection with railroad issues before and since the Securities Act reveals a much more complete disclosure at the present time. Particularly important is the fact that only recently have such prospectuses disclosed the amount of the gross banking spread. 
of course, be distributed by the formation of a subunderwriting group after the effective date, but by that time liability will already have been shouldered, at least in substantial part, by the members of the selling group who subscribe for securities immediately after the effective date.

Another factor responsible for the larger purchase groups is the civil liability which each underwriter bears towards purchasers of securities, under Section in (e) of the Securities Act. Since this section provides that the limit of such liabilities shall be "the total price at which the securities underwritten by him (the underwriter) and distributed to the public were offered to the public," it has seemed desirable for each firm to limit the amount of securities of which it is technically the underwriter, and hence reduce its contingent liabilities. Thus, it has been the general policy to permit many houses to enter into contracts with the issuer, each house making a several purchase of a portion of the issue. By this means the liability of each firm has been limited to that portion purchased by it, and the larger the group, the greater the opportunity for each firm to reduce its contingent liability and underwriting risk.

For these reasons, it has been customary for a rather large group to contract with the issuer, and for the purchase liability and the Securities Act liability for an issue to be spread, as soon as assumed, over five to twenty-five firms, and sometimes more, depending on the size of the issue. In effect, the purchase group is thus formed before the underwriting agreement is signed and the first two stages of the old syndication process are combined into one.

A somewhat different method was tried experimentally some months ago. The registration statement for an issue became effective without complete information having been filed as to underwriting arrangements, price, etc. After the effective date, an underwriting contract was signed, and immediatcly thereafter the underwriter made an offering to sub-underwriters, the latter agreeing to take up any securities not sold to the selling group. By this means the underwriter distributed his liability as soon as he assumed it from the company. After that, a post-effective amendment completed the registration statement and the issue was offered. Howcver, this practice required special treatment of amendments and registration statements by the Securities and Exchange Commission, and, at the present writing, the Commission's policy is not to permit such amendments. ${ }^{13}$

Whether or not sub-underwriters are desirable cannot now be stated. Their services are likely to be most useful when more speculative issues appear in more substantial quantity, and when the market is more a buyers' than a sellers' one. However, it is also possible that sub-underwriting after the effective date will be a satisfactory solution to the problem.

Because of the fact that most recent bond issues have been for the purpose of refunding outstanding obligations, negotiations and investigations preliminary to each issue have been somewhat restricted. Furthermore, there has been no use of finders

${ }^{12} \mathrm{Sec} N . Y$. Times, Aug. 12, 1936, and also June 16, 17, 1936. 
in connection with such financing, since firms with established relationships have generally engaged in these flotations. ${ }^{14}$ In the case of stock financing, however, it would appear that the employment of finders and the process of investigation are much the same as prior to the Securities Act.

Of particular significance is the change in the type of contract which the purchase group members or underwriters make with the vendor corporation. In the case of high grade bond issues, most commitments before the Act were unconditional agreements for outright purchase by the banker. Today, in contrast, there is fairly general use of a broad and sweeping type of hedge clause which is generally called the "market" or "market out" clause. ${ }^{15}$

\section{A typical example of what we refer to as a "market clause" follows:}

"_. \& Co., as representative of the Underwriting Group, may, in its discretion, terminate this agreement without liability on the part of the members thereof if, prior to the time for delivery:

"(2) Any substantial change in the financial position of your Company, or any subsidiary, or in the existing operating, political, economic or market conditions shall have taken place, which, in the judgment of - $\&$ Co., as the representative of the Underwriting Group, with the concurrence of Underwriters who, together with it, have agreed to purchase not less than $50 \%$ of the aggregate principal amount of the Bonds, renders it impracticable or inadvisable to market the Bonds at the price to the public named in paragraph - ."

It will be noted that this clause differs from the so-called "force majeure" clause ${ }^{10}$ in that it covers "any substantial change in political, economic, financial, or market conditions" and is not restricted to those of a catastrophic and necessarily rare character, but may include, as well, those relatively small fluctuations in prices which occur frequently.

The revival of financing in 1935 was accompanied by a rather widespread use of such clauses. More recently, there has been a tendency on the part of some firms to

"This is true even when the firms have been newly organized, for in such cases connections which partners or offeers had previously developed have, to a large extent, been the basis on which participations in recent issues have been secured. There has, of course, been some realignment of participants on the basis of new associations and the development of new distributing organizations.

is In addition to the use of "rnarket clauses," there have been many other changes in the form of purchase contracts. There is a much greater disclosure of the terms on which the underwriters propose to offer an issue, and adherence to such terms has been made a part of the contract. This information includes the public offering price, spreads to dealers, permissible reallowance concessions by selling group members to other dealers, and in some cases other details of the selling group agreement. Frequently the contracts provide for the payment of the bankers' counsel fees by the issuer (although this seems to have been fairly common before 1933) and in some cases where newspaper prospectuses have been employed the issuer has agreed to make payment of some of the costs of advertising.

10 "If . . - prior to the closing date there shall have occurred anywhere any major catastrophe, such as the outbreak of war, national calamity, act of God, or panic, which materially disrupts the financial markets of the United States, and which, in the judgment of such number of Underwriters as have in the aggregate agreed to purchase more than $50 \%$ of the principal amount of the Bonds, renders it impracticable or inadvisatle to consummate the public sale of the Bonds at the price and in the manner above provided ... then, in any such case, the Underwriters, or any of them, shall have the right, in their or its discretion, to terminate their or its obligation under this agreement by notifying the Company by telegraph or telephone and confirmed in writing at the Company's office. . . ." 
drop these "hedges" and to make firm commitments; but despite a decrease in the use of the "market clause," it is nevertheless much more widely employed in bond financing than was the case prior to the Act.

The principal and most vital factor in the use of market clauses is the time during which they may be exercised. In some cases, the underwriters may cancel because of changed market conditions only up to the date of public offering. In others, they may cancel up to some time after the date of public offering-usually the date of delivery of bonds by the company and payment for them by the underwriters. In the latter case, there is almost a legal nullification of the purchase, since the underwriter then has the option of avoiding his liability in case market conditions change in such a way as to make it impossible for him to sell the issue immediately, at the price previously selected.

The significance of such market clauses is open to varying interpretations. It is claimed that clauses of this type are not new, and it is true that they were used quite widely prior to the Securities Act. However, for the most part, such use was restricted to issues of stock or securities of a more speculative nature, where there were admitted uncertainties in connection with the financing. Moreover, even in such cases, it was not general for the hedge clause to give bankers the right to cancel after a public offering of the issue, and provisions of this sort have been used quite frequently in recent issues, and in many cases of issues of very high quality. The use of such hedge clauses may be a result, in part, of the Securities Act. However, of even greater significance was the general uncertainty of the financial community when the revival in financing occurred and the resultant unwillingness of bankers to tike commitments unless they had securely hedged themselves.

At the present time, however, clauses persist although the need has apparently dwindled, and thus they may represent a definite tendency towards weaker banking commitments, despite the excuses which are made for their use. It is claimed that such clauses represent merely a product of a careful legal drafting, that no banker would actually dare to withdraw from an issue once he had offered it to the public since to do so would destroy his reputation, and furthermore that no one has used such clauses in any case. As to the last, the absence of cancellations because of the "out" clause would seem to have been, in large part, the result of the condition of the securities market and the fact that there has been little or no need to withdraw from the flotation of recent securities. As to the ruination of the banker's reputation which would follow if such cancellation occurred, a good case on the other side can be made for the strengthening of his position with customers and dealers if he were to cancel the sale of an issue, rather than to proceed with its distribution in a declining market, with consequent loss to purchasers and dissatisfaction among dealers. ${ }^{17}$

\footnotetext{
${ }^{17}$ The attempt to avoid liabilities has led to the use of other clauses in underwriting or other contracts, the wisdom and even legality of which are subject to doubt.
} 


\section{B. Syndication}

So far as the retailing of securities is concerned, there has been no great change from the methods in vogue prior to the Securities Act. By the end of the 'twenties the selling group had become the dominant type of retail syndicate, although it is true that other forms of syndicate were used. Therefore, the fact that at present we find only the selling group is not a change, but merely an extension of a trend already observable prior to the securities legislation of 1933 and 1934 .

There have, of course, been some changes in the process of forming the selling group, because of the twenty-day waiting or "cooling" period and other features of the Securities Act. Some of the mechanical changes are also the result of the Code of Fair Competition for Investment Bankers and the retention of some provisions of this code by many of the banking firms. For example, it has been the practice for many firms, when acting as originating banker and manager of the purchase group, to send preliminary information to dealers two or three days before the effective date of the registration statement for the issue about to be distributed. Such preliminary material includes "red herring"18 prospectuses and preliminary selling group letters. These contain all the facts in connection with the issue and the selling group, except such items as price, banking commissions, amount of participation, profit, etc. When the registration statement becomes effective, the manager sends out complete prospectuses and selling group contracts. This preliminary notice, which helps to disseminate the data made publicly available in the registration statement, is not required by the Securities Act of 1933, and is thus clearly a result of the Code, which provided for a three-day notice to dealers of selling syndicate and selling group participations.

A further change in the form of operation of present retailing and wholcsaling is found in the method by which purchase group members or underwriters retail a share of their participations. In the 'twenties, it had been customary for each purchase group member, at least those who wished to retail securities, to take a participation in the selling group or syndicate equal to a part of his purchase group participation. Since the selling group theoretically purchased bonds from the purchase group, such a firm would in effect be selling bonds to itself. Recently such resales have involved transfer taxes in the case of bond issues, while there had been no such taxes in the 'twenties, so that it became advisable to eliminate this unneces-

\footnotetext{
${ }^{23}$ This term arises from the fact that across the face of these preliminary documents there is usually printed or stamped in red ink a legend somewhat in the following form: "A Registration Statement relating to the proposed security referred to herein has been filed with the Securities and Exchange Commission under the Securities Act of 1933, as amended, but has not yet become effective. The information contained herein is given circulation solely for informative purposes and is subject to correction and change without notice. Under no circumstances is it to be considered a prospectus or as an uffer to sell or the solicitation of an offer to buy the proposed security referred to herein, and no offer to buy or sell such proposed security should be made nor will such offers be accepted either by the Company or by any of the prospective Underwriters prior to the effective date of the Registration Statement, and the offering of the security. Such offers should be made only on the basis of the authorized Prospectus if and when issued after the effective date of the Registration Statement."
} 
sary resale. Consequently, at the present time, purchase group members retain a portion of their participations and offer only the remaining portion to the selling group. However, since they are bound by the purchase group agreement to obey all selling group restrictions in retailing their securities, the effect is the same as if they were selling group members, except that they are aware of the extent of their commitments prior to the dealers.

In this connection, it has been suggested that purchase group members are now retailing for their own account a larger portion of their purchase group participations than they did in the 'twenties. At the present time, this percentage runs from forty to sixty percent for most houses and is probably closer to the higher figure. Although we have no strictly comparable information for the period prior to the Act, it would appear that this percentage is higher than that prevailing in the 'twenties.

In general purpose and form, it is clear that the syndicate mechanism of the present is not radically changed from that existing prior to the Securities Act of 1933. The aim is still to sell securities rapidly and widely. As part of this, pegging, fixing and stabilizing is still regarded by bankers as necessary, in order that a fixed public offering price may be maintained. However, two factors have tended to limit the need for syndicate trading accounts in connection with the distribution of most recent issues and similarly have restricted the amount of oversales. In the first place, the market for high grade bonds (which comprise the bulk of syndicated securities) has been strong and generally rising and new issues have been restricted mostly to relatively stable refunding operations. In the second place, new issues are, for the most part, no longer traded on exchanges during the period of distribution: Securities can not be traded on an exchange on a "when issued" basis (except issues offered to holders of securities already traded on an exchange, providing such issues will themselves be traded on an exchange). Moreover, admission to unlisted trading privileges is no longer generally possible and admission to regular listing, during the life of the purchase and selling groups, has recently not been the practice. This absence of a listed and widely publicized market probably limits the activity of new issues and the need for substantial trading account activity to peg the price.

In only about one-third of recent bond issues have trading accounts been used and the activity of such accounts has generally been lower than that found in the late 'twenties, with purchases averaging about $3 \%$ to $4 \%$ of the amount of offering or about one-half of the ratio observed in the earlier period. ${ }^{19}$

Undoubtedly of great influence upon such pegging and stabilizing has been the Securities Exchange Act of 1934 which provides in Section 9(a)(6):

"Sec. 9 (a) It shall be unlawful for any person, directly or indirectly, by the use of the mails or any means or instrumentality of interstate commerce, or of any facility of any national securities exchange, or for any member of a national securities exchange ..."

"(6) To effect either alone or with one or more other persons any series of transactions

19 See p. so, supra. 
for the purchase and/or sale of any security registered on a national securities exchange for the purpose of pegging, fixing, or stabilizing the price of such security in contravention of such rules and regulations as the Commission may prescribe as necessary or appropriate in the public interest or for the protection of investors."

Although the Commission has, as yet, made no specific rules on the subject, the existence of penalties in cases where it is adjudged that transactions were manipulative in nature, rather than stabilizing, has probably limited trading account activities. ${ }^{20}$

\section{Distribution}

The scepe of distribution is still wide, and in most recent issues selling groups have been composed of dealers from all parts of the country. Table II indicates the geographic distribution of underwriters' sales and selling group participations of eleven recent bond issues, and shows sales made in practically every section of the country.

Perhaps of more importance than this widespread distribution, has been the great concentration of demand for recent bond issues among institutions. Our present system of distributing securities has been organized to sell throughout the United States to many scattered purchasers. Yet, it is clear that many recent issues could have been sold to a very small number of insurance companies and banks. The importance of institutional buying is illustrated by Table III which presents a classification of purchasers for seven large issues sold during 1935. It is further shown by the accompanying Table IV indicating the extent to which new security purchases by life insurance companies move with total new flotations, and the apparent portion of such flotations taken by insurance companies.

The story from such data is clear-institutions are buying most of the new bond issues. This condition has led to situations in the distribution of some of the recent refunding bonds where an insurance company, in order to get as large a portion of the issue as it wished, has been forced to purchase from more than 100 dealers. It would appear, therefore, that the syndicate mechanism set up for the purpose of wide distribution has not been necessary in the case of many recent issues, and, on the contrary, may have been distinctly unnecessary. In reply to such contentions, however, it is suggested by investment bankers that, if it be necessary to have this type of mechanism for the distribution of issues of a type different from present high grade refundings, then it is necessary to give the dealers some

\footnotetext{
${ }^{\infty}$ Because of limitations of space, we have not discussed secondary distribution. This very important phase of investment banking involves either the distribution of unsold portions of new issues at some time soon after the termination of the syndicates concerned with the primary sale, or the redistribution of blocks of outstanding issues too large to be sold through customary market channels. Secondary distribution is particularly important from the point of view of the problem of the trading account because there is generally an established open market in the issue. Distribution in the face of active markets has, in many cases, been accompanied by substantial volume in the trading account. In seven secondary distributtions of stock during the period 193 I-34, the total volume of purchases and sales of the trading accounts averaged about $65 \%$ of the amount of securities offered, and in one issue, was over $200 \%$.
} 
Table II. Geographic Distribution of Retail Sales of Eleven Registered Bond Issues Sold During 1935*

(In Percentages of Total Amount of the Issues)

\begin{tabular}{|c|c|c|c|}
\hline Estimated Retail Sales in: & $\begin{array}{l}\text { Total: } \\
11 \text { Issues }\end{array}$ & Estimated Retail Sales in: & $\begin{array}{l}\text { Total: } \\
11 \text { Issues }\end{array}$ \\
\hline 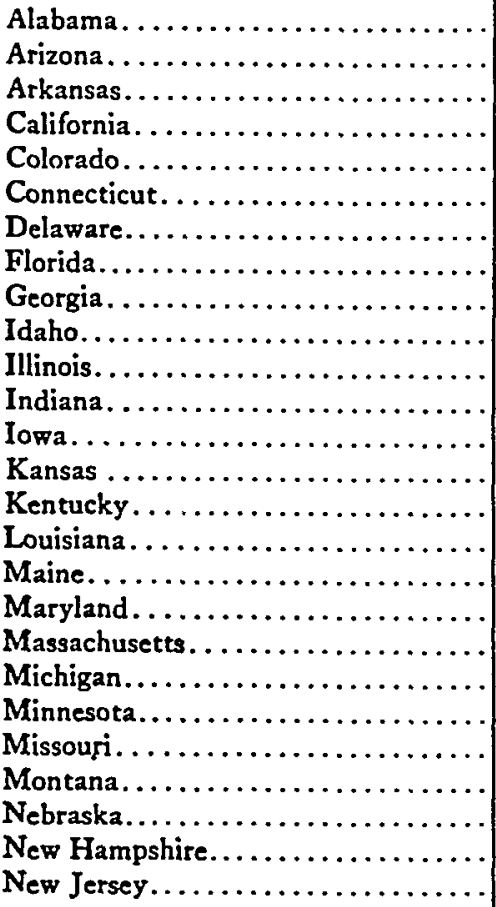 & $\begin{array}{r}.06 \\
.02 \\
.02 \\
7.78 \\
.23 \\
3.14 \\
.35 \\
.10 \\
.38 \\
.01 \\
6.97 \\
1.12 \\
.88 \\
.06 \\
.32 \\
.18 \\
.95 \\
1.49 \\
10.65 \\
.90 \\
1.25 \\
1.21 \\
.03 \\
.54 \\
.52 \\
3.01\end{array}$ & 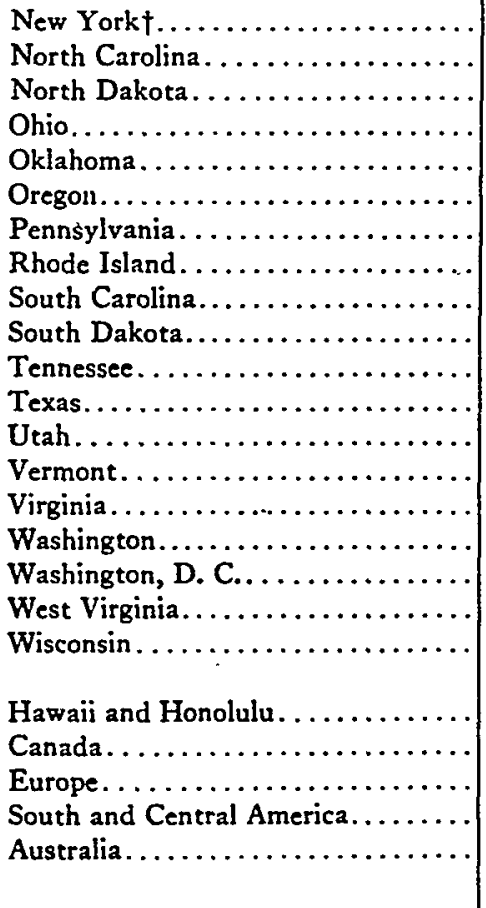 & $\begin{array}{r}36.43 \\
.01 \\
.01 \\
2.27 \\
.06 \\
.32 \\
9.67 \\
.74 \\
.02 \\
.02 \\
.30 \\
.25 \\
.05 \\
.49 \\
.32 \\
.91 \\
.72 \\
.06 \\
1.58 \\
.06 \\
3.53 \\
.02 \\
.002 \\
.0003\end{array}$ \\
\hline
\end{tabular}

- Based on the actual location of retail alez of purchase group members, and the location of dealers to whom selling group participations were given. It has been eatimated that these figures ase over $90 \%$ correct an an indication of retail sales for the $\$ 398,600,000$ of bondi covered.

In seneral, these data reflect primarily the location of distribution facilities rather than the location of wealth and population, 2 lthough there is much inter-relationship between these.

tNew York sales include asles to houses which, through branches, distribute outside this area.

business in the present issues in order to keep them alive for such subsequent operations. Perhaps more important is the desire of most issuing corporations to achieve a wide distribution of their securities, in order that they will not be dependent upon a restricted demand in future financing, and in order generally to improve their credit standing.

\section{E. Private Placing}

This concentrated institutional demand has made possible the use of private placing as a method of distribution. This method involves the distribution of an issue to a limited number of purchasers, through the agency of a banker or other intermediary, or directly by the corporation. It does not necessitate registration under the 1933 Act, if there is no public offering in the sense of the Act. Its early use was stimulated by a desire to avoid the liabilities of the Securities Act and it 
Table III. Chassipicatton of Buyers for Seven Issues Registered Under the Securittes Act of 1933 aNd Sold During 1935"

(In Percentage of Total Sales Taken by Each Class)

\begin{tabular}{|c|c|c|c|c|c|c|c|}
\hline \multirow{2}{*}{ Type of Buyers } & \multicolumn{7}{|c|}{ Issues } \\
\hline & $A$ & B & C & D & E & F & G \\
\hline Trust Companies and Commercial Banks. & 58.0 & 62.7 & 63.2 & 28.3 & 48.1 & 61.2 & \}$_{52}$ \\
\hline Savings Banks........ & 10.6 & 2.8 & 0.4 & 7.2 & 1.0 & 1.1 & \\
\hline Life Insurance and Other Insurance Companies.. & 12.2 & 3.8 & 4.3 & 46.0 & 18.1 & 16.2 & 40.2 \\
\hline 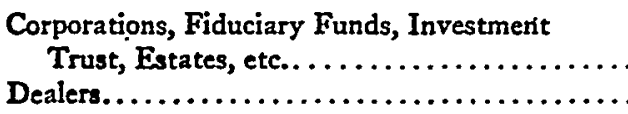 & $\begin{array}{l}7.2 \\
5.4\end{array}$ & $\begin{array}{r}10.4 \\
7.1\end{array}$ & $\begin{array}{r}10.8 \\
2.4\end{array}$ & $\begin{array}{l}9.5 \\
0\end{array}$ & $\begin{array}{r}12.5 \\
3.7\end{array}$ & $\begin{array}{l}8.6 \\
2.0\end{array}$ & $\begin{array}{l}4.0 \\
0.7\end{array}$ \\
\hline Individuals.... & 6.6 & 13.2 & 18.9 & 9.0 & 16.6 & 10.9 & 2.7 \\
\hline Total...... & 100.0 & 100.0 & 100.0 & 100.0 & 100.0 & 100.0 & 100.0 \\
\hline
\end{tabular}

These dsta represent the experience of the retail selling organizations of originating houses which were members of the purchare groups of the particular issues. They represeat the distribution only of that portion of the commitmeat aot released to the selling group, and do not neceusarily represent the distribution expesieace for the whole of these isules.

has continued on the theory that (a) it costs the issuing corporation less to float securities in this manner than through customary underwriting channels, and (b) the buyer gets the securities at a better price. These reasons are not altogether convincing, however. It is possible that any saving in distribution expenses to the seller may be outweighed by a sales price lower than that which would result from public sale. On the other hand, the advantage to the buyer of a lower purchase price may be counteracted by limited marketability for the issue. As a general matter, private placing has the disadvantage of denying the transaction the test of a public offering, with accompanying disclosure. This publicity, in itself, tends to limit the possibility of an unfair bargain for either party to the transaction.

Table $\mathrm{V}$ indicates the estimated volume of such private placings during the period of the effectiveness of the Securities Act, as compared with the volume of all security flotations. All such sales have been to a limited number of institutions. Sometimes one insurance company or bank purchased the whole issue, and rarely were there more than eight or ten participants in such purchase.

\section{F. General Results of the Securities Act}

The effects of the Securities Act in producing changes in the mechanical operations of investment banking have been indicated. More significant, however, are its effects upon the background and environment of security distribution.

The Securities Act imposes certain definite and potentially severe liabilities upon underwriters, and it is probable that the mere existence of such liabilities has made bankers more cautious and more conscious of the full meaning of the welfare of 
Table IV. Comparison of New Security Purchases of Life Insurance Companies with Total Flotations of Bonds Registered Under the Securities Act of 1933

(Thousands of Dollars)

\begin{tabular}{|c|c|c|}
\hline & $\begin{array}{l}\text { Public Utility and } \\
\text { Miscellaneous Bond } \\
\text { Purchases of Selected } \\
\text { Life Insurance Com- } \\
\text { panies* }\end{array}$ & $\begin{array}{c}\text { Gross Proceeds } \\
\text { of Bond Issues } \\
\text { Registered Under } \\
\text { the Securities Act } \\
\text { of } 1933\end{array}$ \\
\hline 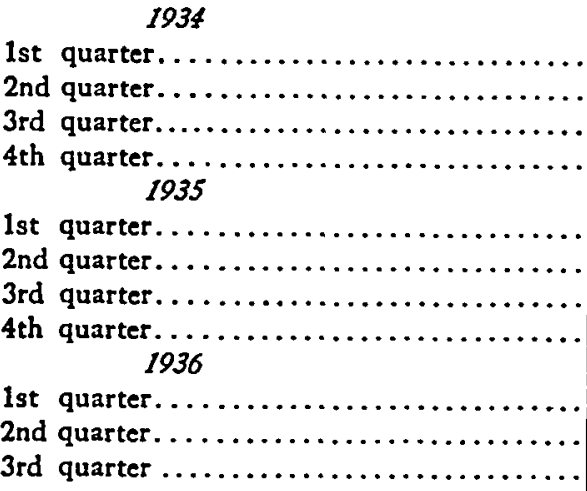 & $\begin{array}{r}34,340 \\
46,756 \\
59,321 \\
93,759 \\
\\
121,127 \\
161,245 \\
254,295 \\
236,313 \\
\\
144,883 \\
271,099 \\
326,422\end{array}$ & $\begin{array}{r}\$ 15,950 \\
14,033 \\
46,092 \\
58,750 \\
98,550 \\
345,426 \\
829,337 \\
636,912 \\
\\
839,706 \\
1,002,551\end{array}$ \\
\hline
\end{tabular}

Source: Thall Strect Journal.

investors. On a broader scale, this caution has been imposed by Section 15 of the Securities Exchange Act of 1934, and the broker-dealer registration thereunder. The fact that a violation of the Securities Act is ground for revocation of broker-dealer registration, without which no firm can engage in over-the-counter trading in interstate commerce, has led to greater care on the part of retailers as well as wholesalers of securities. While it is true that registration and regulation do not change or raise the moral standards of a business community overnight, they can gradually emphasize the desirability of and needs for a better code of ethics. The securities legislation acts as a constant reminder of better standards, and limits the extent to which unethical practices will prove profitable. The higher standards to which many members of the industry would always adhere, if it were not for the pressure of competition, thus tend to be imposed upon everyone. ${ }^{21}$

A basic change in the environment of securities distribution has, of course, resulted from Section 8(a) of the Securities Act which provides:

"The effective date of a registration statement shall be the twentieth day after the filing thereof, except as hereinafter provided, and except that in case of securities of any foreign public authority, which has continued the full service of its obligations in the United States, the proceeds of which are to be devoted to refunding of obligations payable in the United States, the registration statement shall become effective seven days after the

${ }^{21}$ Coopperative efforts of the Securities and Exchange Commission with the Investment Bankers Conference Committee, and now with the Investment Bankers Conference, Inc., represent a more informal atempt to improve the standard of investment banking throughout the United States, by means other than the threat of legal penalties. 
Table V. The Volume of Corporate Private Placings in 1935 and 1936

(Gross Proceeds of Issues Offered for Sale)

\begin{tabular}{|c|c|c|c|c|c|c|c|}
\hline \multirow[b]{2}{*}{1935} & \multirow{2}{*}{$\begin{array}{c}\text { Total } \\
\text { Corporate } \\
\text { Issues* } \\
\$ 000,000\end{array}$} & \multicolumn{2}{|c|}{$\begin{array}{l}\text { UNRegistered Pri- } \\
\text { VAte Placings }\end{array}$} & \multicolumn{2}{|c|}{$\begin{array}{l}\text { Registered Pri- } \\
\text { vate Placings }\end{array}$} & \multicolumn{2}{|c|}{$\begin{array}{l}\text { Total Private } \\
\text { Placinos }\end{array}$} \\
\hline & & $\$ 000,000$ & $\begin{array}{c}\text { Percent of } \\
\text { Total } \\
\text { Issues }\end{array}$ & $\$ 000,000$ & $\begin{array}{c}\text { Percent of } \\
\text { Total } \\
\text { Issues }\end{array}$ & $\$ 000,000$ & $\begin{array}{c}\text { Percent of } \\
\text { Total } \\
\text { Issues }\end{array}$ \\
\hline 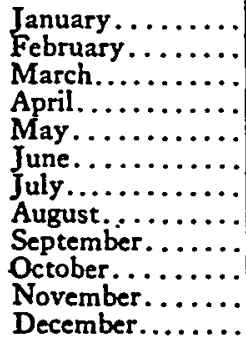 & $\begin{array}{r}47 \\
41 \\
113 \\
124 \\
152 \\
178 \\
509 \\
160 \\
259 \\
294 \\
242 \\
199\end{array}$ & $\begin{array}{l}46 \\
39 \\
0.4 \\
7 \\
33 \\
51 \\
13 \\
32 \\
16 \\
25 \\
31 \\
4\end{array}$ & $\begin{array}{r}97.9 \\
95.1 \\
0.4 \\
5.7 \\
21.7 \\
28.6 \\
2.6 \\
20 \\
6.1 \\
8.5 \\
12.8 \\
2\end{array}$ & $\begin{array}{r}0 \\
0 \\
0 \\
2 \\
0 \\
0 \\
52 \\
1 \\
3 \\
1 \\
0 \\
10\end{array}$ & $\begin{array}{l}0 \\
0 \\
0 \\
1.6 \\
0 \\
0 \\
10.2 \\
.6 \\
1.2 \\
.3 \\
0 \\
5\end{array}$ & $\begin{array}{l}46 \\
39 \\
0.4 \\
9 \\
33 \\
51 \\
65 \\
33 \\
19 \\
26 \\
31 \\
14\end{array}$ & $\begin{array}{r}97.9 \\
95.1 \\
0.4 \\
7.3 \\
21.7 \\
28.6 \\
12.8 \\
20.6 \\
7.3 \\
8.8 \\
12.8 \\
7\end{array}$ \\
\hline Total........ & 2,318 & 297.4 & 1.3 & 69 & .2 & 366.4 & 1.5 \\
\hline 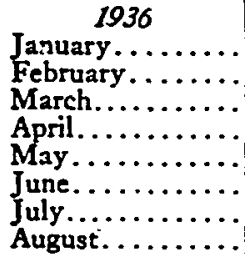 & $\begin{array}{l}257 \\
150 \\
498 \\
672 \\
280 \\
595 \\
406 \\
244\end{array}$ & $\begin{array}{r}36 \\
9 \\
25 \\
7 \\
0 \\
15 \\
78 \\
0\end{array}$ & $\begin{array}{c}14 \\
6 \\
5 \\
1 \\
0 \\
2.5 \\
19.2 \\
0\end{array}$ & $\begin{array}{r}4 \\
2 \\
1 \\
7 \\
79 \\
10 \\
0 \\
0\end{array}$ & $\begin{array}{c}1.6 \\
1.3 \\
1.2 \\
1 \\
28.2 \\
1.7 \\
0 \\
0\end{array}$ & $\begin{array}{r}40 \\
11 \\
26 \\
14 \\
79 \\
25 \\
78 \\
0\end{array}$ & $\begin{array}{c}15.6 \\
7.3 \\
5.2 \\
2 \\
28.2 \\
4.2 \\
19.2 \\
0\end{array}$ \\
\hline$\underset{\text { (8 Motal.......... }}{\text { Tos.) }}$ & 3,102 & 170 & 5.5 & 103 & 3.3 & 273 & 8.8 \\
\hline
\end{tabular}

Total corporate issue (exclusive of inveatment eruser) for which here appeared a record of offering in the finacial neme papers or Commercial and Financial Chronicle. Isuves of less than $\$ 100,000$ are not covered.

filing thereof. If any amendment to any such statement is filed prior to the effective date of such statement, the registration statement shall be deemed to have been filed when such amendment was filed; except that an amendment filed with the consent of the Commission, prior to the effective date of the registration statement, or filed pursuant to an order of the Commission, shall be treated as a part of the registration statement."

Since the registration statement requires a full and complete disclesure of ali the essential matters concerning an issue, this provision means that, for a period of twenty days, there is public knowledge of important facts concerning the issuing corporation and the issue. Of course, the average buyer does not see the registration statement, but leading statistical services and financial journals analyze carefully each large statement immediately or soon after filing, and publish important facts disclosed therein. Moreover, the Commission itself releases certain information with respect to large issues.

Therefore, there is considerable information easily available to the buyer before the offering date as a result of the registration requirements of the Act, and such information is also available to those sources from which the buyer might receive investment advice. This has altered considerably the practice, formerly typical in 
many distributions of securities, of releasing issues with a minimum of prior disclosure and of "high pressuring" them so that the buyer was apparently forced to make a rapid decision with respect to purchase, without anybody having had an adequate opportunity to study the issue or examine even such small amount of information as was available.

While the twenty day waiting period has thus provided more information, it should not be concluded that all data are available during the whole of this "cooling" period. For example, it has been the practice for the final offering price of the issue and information with respect to underwriting contracts, spreads, and underwriting participations to be filed only two or three days before the twentieth day after original filing of the statement. The Commission has cooperated in this practice by regarding such amendments as having been filed nunc pro tunc, so that the whole statement becomes effective on the twentieth day after original filing. However, even when this is the practice, there is some lapse of time between the public filing of the information and the public offering, so that there is no sudden release of the issue.

While this disclosure of information has apparently been of benefit to the public and buyers of securities in general, it has been claimed that the twenty day cooling period complicates the syndication process because of the opportunity it provides for a practice known as "beating the gun." The essence of the practice of "gun-beating" is an offering to the public prior to the public offering date. When such an offering is made by a participant in any of the syndicates, it is in violation of an agreement he has signed. Moreover, in the case of a proposed offering of securities under circumstances requiring registration, any premature partial offering of such securities prior to the public offering date wouid generally be made in advance of the effective date of registration and would therefore be in violation of the Securities Act.

It is claimed that "beating the gun" disturbs the orderly process of distribution by injecting an element of unfair competition, to the extent that some dealers, by indulging in this practice, are able to take advantage of those who abide by syndicate terms. It is further claimed that the practice is stimulated because of the availability of information both to buyers and sellers during the whole of the "cooling" period prior to the effective date of the registration statement.

In viewing this complaint, it should be borne in mind, however, that the practice is not new, but existed prior to the Securities Act. Apparently, therefore, although it is true that the "cooling" period does give more time for premature solicitation, some of the reasons for "gun-beating" are connected with conditions of the business other than the Securities Act, factors which operated in the 'twenties as well as at the present time. Moreover, certainly a large part of the stimulus to "gun-beating" has come from the fact that new securities have been scarce, prices have been attractive to institutional buyers, and, consequently, there has been a greater demand and pressure for securities than we are likely to find in more normal markets. This 
Table VI. Participations of Leading Firms as Underwruters in Bonds and Stocks Registered Under Securities Act of I933

Offered for Sale prom Jan. I, I935 Throvgh Sept. 30, 1936*

(Thousands of Dollars)

\begin{tabular}{|c|c|c|c|c|c|c|c|}
\hline & \multicolumn{3}{|c|}{ Bonds } & \multicolumn{3}{|c|}{ Stocks } & \multirow{2}{*}{$\begin{array}{c}\begin{array}{c}\text { ALL } \\
\text { IssuEs }\end{array} \\
\underset{\mathbb{E}}{\mathbb{B}}\end{array}$} \\
\hline & 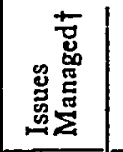 & 岕总 & 㺃 & 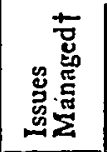 & 点总 & $\stackrel{\overrightarrow{5}}{\circ}$ & \\
\hline 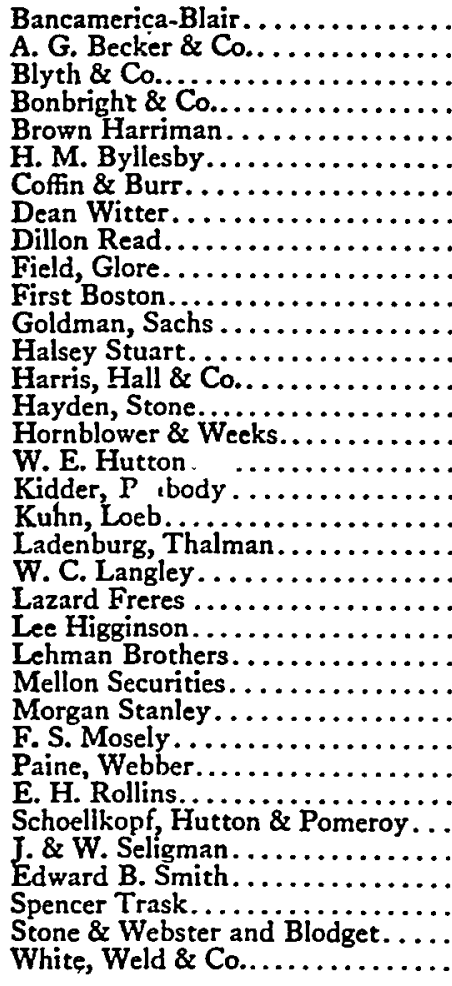 & $\begin{array}{r}4,400 \\
53,184 \\
38,048 \\
14,260 \\
0 \\
11,958 \\
4,723 \\
75,755 \\
16,571 \\
135,736 \\
13,771 \\
31,552 \\
4,325 \\
13,000 \\
7,450 \\
8,650 \\
4,000 \\
189,017 \\
0 \\
10,900 \\
24,300 \\
1,800 \\
9,325 \\
19,500 \\
180,528 \\
2,000 \\
8,013 \\
1,292 \\
0 \\
66,664 \\
0 \\
19,617 \\
3,218\end{array}$ & $\begin{array}{r}23,796 \\
16,667 \\
155,184 \\
71,669 \\
252,348 \\
48,750 \\
23,515 \\
48,705 \\
32,550 \\
87,809 \\
212,002 \\
36,956 \\
61,656 \\
24,946 \\
59,075 \\
10,375 \\
27,540 \\
97,358 \\
104,375 \\
19,700 \\
33,715 \\
99,194 \\
83,536 \\
71,405 \\
67,028 \\
28,475 \\
27,149 \\
17,600 \\
55,547 \\
24,075 \\
31,668 \\
175,214 \\
26,576 \\
38,466 \\
59,533\end{array}$ & $\begin{array}{r}28,196 \\
16,667 \\
208,368 \\
109,717 \\
266,608 \\
48,750 \\
35,473 \\
53,428 \\
108,305 \\
104,380 \\
347,738 \\
50,727 \\
93,208 \\
29,271 \\
72,075 \\
17,825 \\
36,190 \\
101,358 \\
293,392 \\
19,700 \\
44,615 \\
123,494 \\
85,336 \\
80,730 \\
86,528 \\
209,003 \\
29,149 \\
25,613 \\
56,839 \\
24,075 \\
31,668 \\
241,878 \\
26,576 \\
58,033 \\
62,751\end{array}$ & $\begin{array}{r}0 \\
6,270 \\
1,120 \\
6,312 \\
1,538 \\
769 \\
0 \\
3,845 \\
19,043 \\
4,081 \\
2,061 \\
3,596 \\
0 \\
0 \\
14,525 \\
5,288 \\
4,059 \\
4,339 \\
4,336 \\
0 \\
0 \\
1,400 \\
0 \\
35,318 \\
0 \\
0 \\
1,122 \\
5,660 \\
861 \\
0 \\
0 \\
7,000 \\
0 \\
325 \\
852\end{array}$ & $\begin{array}{r}1,774 \\
1,436 \\
6,198 \\
1,538 \\
8,100 \\
1,714 \\
2,725 \\
2,335 \\
0 \\
5,042 \\
6,876 \\
8,817 \\
714 \\
5,952 \\
4,923 \\
4,189 \\
3,070 \\
9,760 \\
3,498 \\
1,250 \\
3,500 \\
3,874 \\
11,243 \\
2,310 \\
1,035 \\
4,643 \\
1,467 \\
1,693 \\
1,063 \\
1,186 \\
1,306 \\
3,350 \\
3,173 \\
5,993\end{array}$ & $\begin{array}{r}1,774 \\
7,706 \\
7,318 \\
7,850 \\
9,638 \\
2,483 \\
725 \\
6,180 \\
19,043 \\
9,123 \\
8,937 \\
12,413 \\
70 \\
714 \\
20,477 \\
10,211 \\
8,248 \\
7,409 \\
14,096 \\
3,498 \\
1,250 \\
4,900 \\
3,874 \\
46,561 \\
2,310 \\
1,035 \\
5,765 \\
7,127 \\
2,554 \\
1,063 \\
1,186 \\
8,306 \\
3,350 \\
3,498 \\
6,845\end{array}$ & $\begin{array}{r}29,970 \\
24,373 \\
215,3686 \\
117,567 \\
276,246 \\
51,233 \\
36,198 \\
59,, 608 \\
127,348 \\
113,503 \\
356,667 \\
63,140 \\
93,208 \\
29,985 \\
92,552 \\
28,036 \\
44,438 \\
108,767 \\
307,488 \\
23,198 \\
45,865 \\
128,394 \\
89,, 210 \\
127,291 \\
88,, 838 \\
210,038 \\
34,914 \\
32,740 \\
59,, 393 \\
25,138 \\
32,854 \\
250,184 \\
29,, 926 \\
61,581 \\
69,596\end{array}$ \\
\hline & & & & & & & \\
\hline
\end{tabular}

These statistics do not cover all registered issues, but generally include those isues of which we have a defioite recond of an actual public offering in which the above firms participated.

tIncluded are those issues in connection with which a firm acted with one or more other firms as co-mananer.

Norz: The figures indicate only the smounts for which each firm committed itelf as underwriter, with the exception of the New York Edison 31/4's due 1966 underwitten by Morgan Stanley \& Co. where sub-underwiting commitments were used.

does not mean that the Commission is not concerned with and has not studied this question, particularly to the extent that it relates to violations of the Act. There is a definite impression, however, that violations are much less than they were some time ago, but should the practice become a real problem, ways will be found to cope with it.

As a result of the registration requirements of the Securities Act there is today 
more disclosure of information concerning investment bankers' participation in the distribution of an issue than ever before. The significance of this fact should not be overlooked. Particularly desirable, is the disclosure of the gross spread to bankers. It is exactly this type of information which was impossible to secure prior to the Act. Other information with respect to the type of bankers' commitment and the amount of each underwriter's participation are also of interest and of value. ${ }^{22}$ Considering the fact that secrecy concerning these matters was one of the features of investment banking in the 'twenties, present disclosure must be regarded as a great forward step.

This and other information is available to the buyer of securities not only in the registration statement but also, in increasing measure, in the prospectuses and in some types of newspaper advertisements. The buyer of securities is most aware of the changes caused by the Securities Act to the extent that they have affected the prospectus and newspaper advertising. Section to (a) of the Act outlines the requirements for the prospectus, and, in accordance with the law and the Commission's rules and regulations, the buyer of securities can obtain and, in fact must receive prior to the completion of any sale of securities to him, a copy of the prospectus. The document is a summary, and a rather detailed one, of the information contained in the registration statement. For most issues of large corporations it is undoubtedly a buiky and not particularly readable booklet, and to that extent is not so useful as it might be. This limitation is emphasized by the fact that the mass of security buyers in this country are unable and apparently unwilling to spend a reasonable amount of time in securing facts concerning an issue or advice from sources which might make adequate use of available information. This inertia can not be changed immediately, and, therefore, while the complete prospectus is particularly valuable for technically equipped analysts, its usefulness has not been fully recognized by the general run of security buyers. Consequently, it is desirable that some method be evolved for placing information in the hands of these buyers, so that the required disclosure will be most useful. The Commission is aware of this, and many of its staff have been spending time in considering possibilities and suggesting methods for improving and shortening the prospectus or attaching thereto some form of a summary. Despite all these limitations, the intelligent investor profits from having all necessary information at hand; and even the man who cannot see any use for the data and throws the prospectus away benefits indirectly from the very existence of the prospectus and the widespread disclosure which it brings about.

Despite its limitations, the prospectus exemplifies the changed character of securities distribution which has followed from the-Act. The availability of information, even though it may not be presented as effectively as possible, means that we are approaching a stage when an intelligent investor will have enough correct data to make somewhat more reasonable judgments with respect to securities than he 22 We present in Table VI information on the amount of participations. 
would in the 'twenties. The crux of the situation is to teach the investor to use such data; and the problem of educating investors in this and other directions, upon which the Commission, because of its short life, has only started, is perhaps its greatest task for the future.

The Commission, in its desire to get information before the investor, has also attempted to encourage the use of a type of newspaper advertisement which will present a substantial proportion of the information necessary to the discriminating buyer of securities. In the early stages after the Securities Act, it was customary for most advertisements for registered issues to be of the "tomb stone" type, containing merely the name of the security, the price at which it was being offered and the name of the underwriter or person from whom the prospectus could be obtained. More recently, there has been a growing use of the more complete advertisement, called the "newspaper prospectus," in which most of the important facts concerning the issue, the corporation's business, financial condition and earnings, and underwriting arrangements are set forth in summary form. To the extent that such type of advertising can be used, the -investor, even though he suffer from inertia, will have at hand information concerning an issue, and will receive more and probably more accurate data than was available prior to the Securities Act.

In connection with this matter of changes in investment banking methods caused by the Securities Act, it is frequently claimed that one important change is an increase in a corporation's expenses of issuing securities. Clearly, the issuing corporation does bear substantial expenses in connection with the registration of securities with the Securities and Exchange Commission which did not exist prior to the Act. Such expenses include, in addition to a small filing fee, expenses of printing the registration statement and prospectus, and fees of counsel, accountants, and other experts in connection with the preparation of the statement.

A tabulation of these expenses for a substantial sample of bond issues floated during 1935 and 1936 is presented in Table VII. Excluding commissions to bankers, the estimated costs of registration, preparation, and issuance of securities were $0.70 \%$ of face value. However, only certain of these expenses have been increased by the Securities Act registration requirements. Some legal and accounting fees existed before the Act, as did most of the expenses of listing, transfer agent, trustee, etc. Thus, it appears unlikely that the net increase in expenses, at least for bond issues, has been more than one-third of $x \%$ of face value. Moreover, it is also likely that the trend of such expenses is downward and will continue so as the routine of registration becomes more widely understood. The Commission has attempted to reduce the need for certain expenditures, so far as it can do so consistently with the other aims of the Act. One method has been the promulgation of simpler forms (A-2 instead of A-r) for established companies.

It is admitted, however, that there can be no elimination of the costs of registration, of preparation of more careful accounting data, etc. But the existence of these 
Table VII. Breakdown of Expenses of Registration, Preparation and Issuance of Securities for 86 Bond Issues Sold During i935 and I936*

\begin{tabular}{|c|c|c|c|}
\hline & $(8000)$ & $\begin{array}{c}\text { Percent of } \\
\text { Total }\end{array}$ & $\begin{array}{l}\text { Percent of } \\
\text { Face Value }\end{array}$ \\
\hline 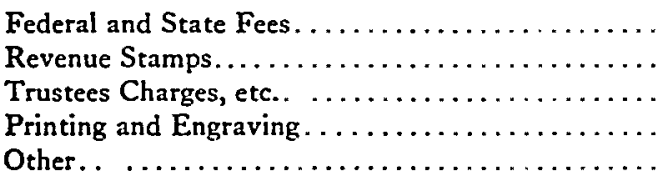 & $\begin{array}{r}\$ 1,194.9 \\
1,706.7 \\
1,554.7 \\
1,549.6 \\
1,179.1\end{array}$ & $\begin{array}{l}10.9 \\
15.6 \\
14.2 \\
14.1 \\
10.8\end{array}$ & $\begin{array}{l}0.077 \\
0.11 \\
0.10 \\
0.10 \\
0.076\end{array}$ \\
\hline Subtotal.................. & $7,185.0$ & 65.6 & 0.46 \\
\hline 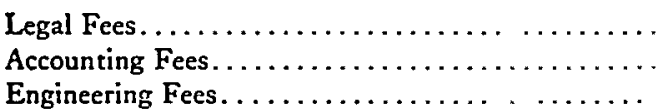 & $\begin{array}{r}2,521.6 \\
1,165.1 \\
82.8\end{array}$ & $\begin{array}{r}23.0 \\
10.6 \\
0.8\end{array}$ & $\begin{array}{l}0.16 \\
0.075 \\
0.005\end{array}$ \\
\hline Subtotal (Expert Charges) ... . . . . . & $3,769.5$ & 34.4 & 0.24 \\
\hline Total. & $10,954.5$ & 100.0 & 0.70 \\
\hline
\end{tabular}

Exclusive of underwriting commission and discount.
Note: This compilaticn covers bond issues with face value of $\$ 1,559,912,000$, sold during 1935 and during the third quarter of 1936 .

costs may be justified. The investor may find it worthwhile in view of the greater publicity of information. More than that, these costs may be compensated or even outweighed by a reduction in other costs.

The gross spread between the public offering price and the price received by the corporation represents the cost of distributing securities and measures the effort required. The accompanying Table VIII indicates the movements of gross spreads

Table ViII. Gross Underwhiting Spreads on Bond Flotations

\begin{tabular}{|c|c|c|}
\hline & $\begin{array}{c}\text { Number of } \\
\text { Issues }\end{array}$ & $\begin{array}{c}\text { Average Spread } \\
\text { (Percent of } \\
\text { Face Value) }\end{array}$ \\
\hline 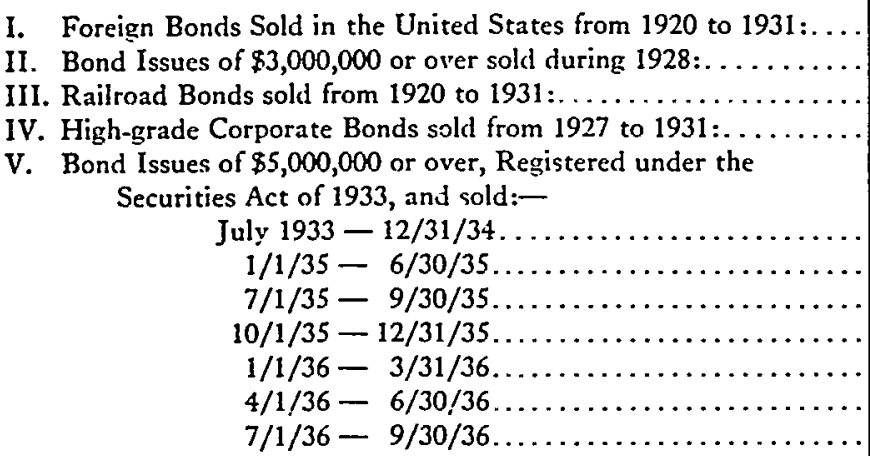 & $\begin{array}{r}290 \\
65 \\
\dagger \\
143 \\
\\
7 \\
14 \\
23 \\
22 \\
15 \\
32 \\
19\end{array}$ & $\begin{array}{l}5.3^{*} \\
4.3^{* *} \\
3 . .^{*} \\
3 . * \\
\\
3.72 \\
2.79 \\
2.33 \\
2.45 \\
2.33 \\
2.18 \\
2.13\end{array}$ \\
\hline
\end{tabular}

\footnotetext{
Figures rounded off to the nearest tenth.
- Percentage of public offering price, but comparable to other data since, on the average, bonds were originally offered at or
} close to face value or $100^{\mathrm{r}} \mathrm{c}$.

†Number of issues is not avalable, but the total face value of such issues was $\$ 3,711,800,000$. 
since the Securities Act. The great activity in bond financing has provided us with a sufficiently large sample and we can safely make comparisons with the apparently reliable data for bond flotations prior to the Act. ${ }^{28}$ The conclusion is clear that spreads are lower today. The averages before the Act were in the neighborhood of $3 \%$ and $4 \%$ of par, with over $80 \%$ of a large sample of bonds floated in Ig28 having spreads of over $2.7 \%$ of public offering price. This compares with averages which, since active financing got under way in 1935 , have been less than $3 \%$ and have rapidly declined to less than $21 / 4 \%$ of par. Apparently, the story is the same for preferred stock issues, with spreads on eighteen such issues sold during 1935 and 1936 averaging about $4 \frac{1}{4} \%$ of the public offering price as compared with $5 \%$ in the 'twenties.

The reasons for this decrease in spread may be traceable to the fact that present issues have been of higher quality, mostly for refunding purposes, and with lower coupon rates. A definite relationship between yields on new bond issues and spreads has been observed as Table IX indicates. In part, however, this decrease may be

Table IX. Correlation Table Between Gross Spreads and Offering Yields to Maturity

(76 Bond Issues, Registered Under Sec. Act of 1933)

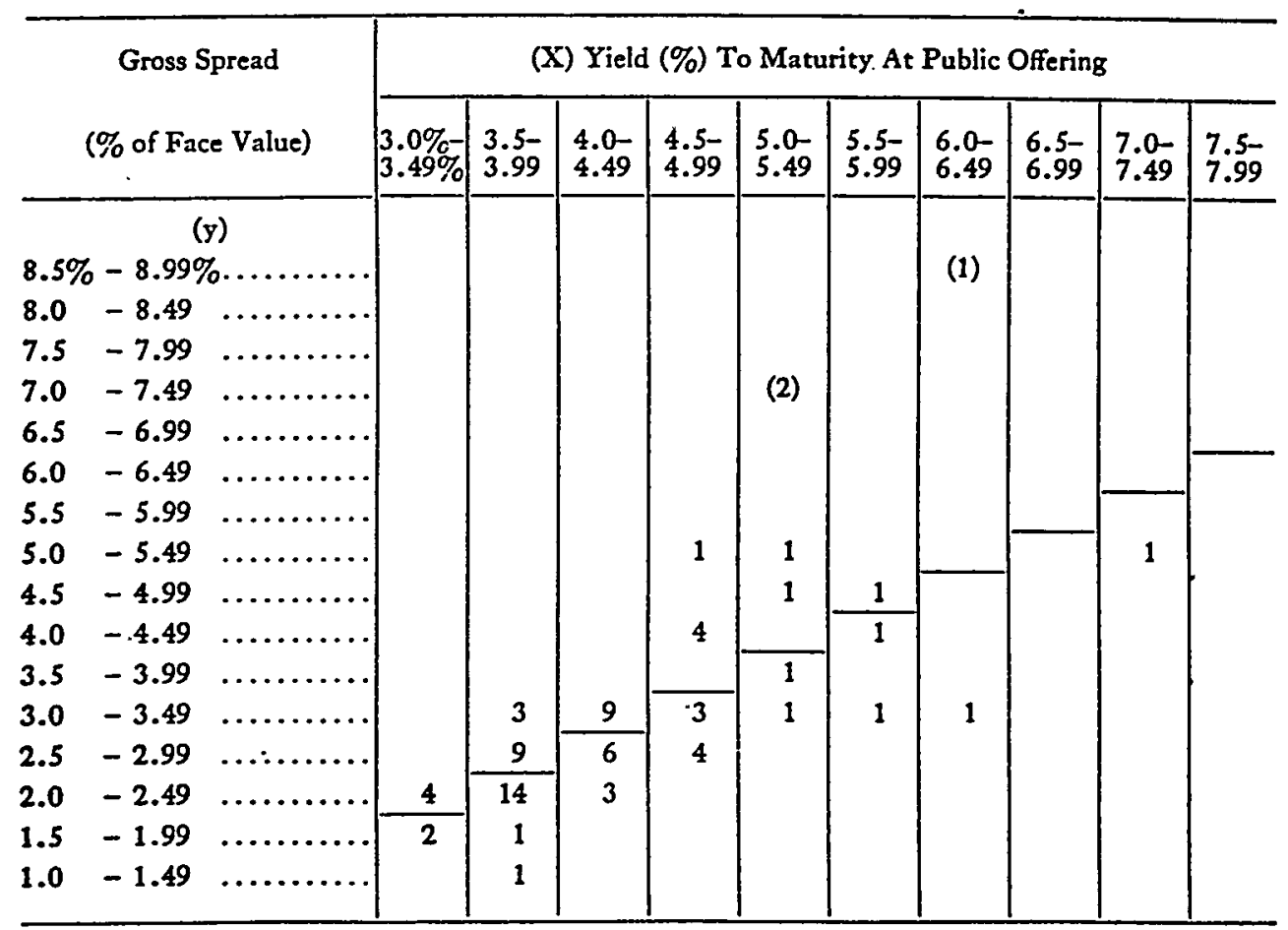

$Y_{r "}=.8798 x-.7914$.

"p" (probalility of chance occurrence of an " $g$ " this large) is less than 01 (one in one hundred).

Norz: Figures in parestheses, (), are excluded from the caleulations.

${ }^{22}$ See pages 50-52, supra. 
due to the fact that registration has simplified the bankers' task in distributing an issue. Nothing very conclusive can be stated on this matter; there is a definite possibility, however, that the Act and the Commission and the new conditions responsible for the legislation have produced savings in underwriting expenses which counteract, in whole or in part, the increased costs of registration.

The positive regulations and penalties of the Securities Act and, perhaps more important, the prophylactic effects of publicity, result in a more careful and responsible preparation of securities. This better construction of the bankers' merchandise tends to reduce sales resistance, and consequently, the costs of selling. If, in addition, the long term quality of the investment merchandise is sufficiently improved to reduce the losses of the investors by only a mere fraction of a per cent, the larger total cost of printing and other registration expenses under the Securities Act may turn out to be a long term gain. A shift from expenditures for salesmanship to expenditures for expert preparation of securities and prospectuses, investigations by bankers, accountants, and lawyers, is a shift which economically is not undesirable.

\section{Conclusion}

The Securities Act of 1933 has not destroyed the mechanism of investment banking, nor even crippled it. Securities are still being distributed efficiently. Thus far, the primary reaction of the industry to the new problems and liabilities of the Act has been for most bankers to attempt to hedge against them, and pass them back to the issuer. This may be only a temporary phase, however. Certainly, there is apparent greater care and awareness of responsibility in processing and distributing securities. More broadly, the Act has achieved the dissemination of informationalthough it still has far to go in this direction; it is aiding in imposing the ethics of the better bankers upon the whole industry; and it has started a generally desirable shift of emphasis from selling to the expert preparation of the investment merchandise. It has done these at little or no additional net cost to the issuer or the buyer of securities, and with a minimum of disturbance to the machinery involved. 